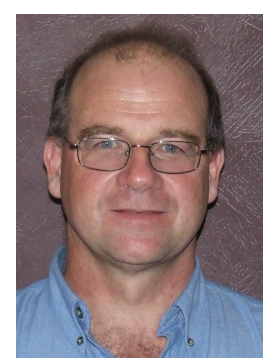

Stuart Robertson

PhD Scholar

CRC for Remote Economic Participation

UNE Business School

University of New England, Australia

\title{
MINE LIFECYCLE PLANNING AND ENDURING VALUE FOR REMOTE COMMUNITIES
}

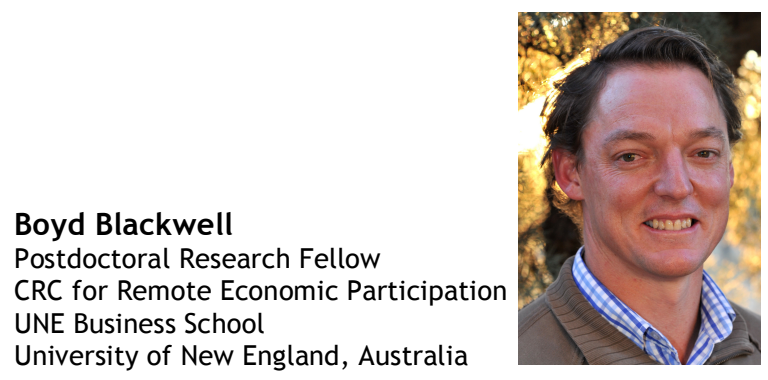

\begin{abstract}
Mine lifecycle planning is critical to developing enduring value from mining for remote communities. The history of mining is replete with examples of communities being unsustainable post mine closure. The concept of enduring value involves ensuring that a sustainable community will remain following the closure of an associated mine. Since 2003, awareness has increased among international and Australian peak mining bodies for the need to plan for enduring community value. This increased awareness has developed alongside requirements that mining companies operate in a socially responsible manner by maintaining their social licence to operate. This paper thematically reviews the literature relevant to mine lifecycle planning, enduring value, socio-economic impacts of mining, and mine closure. Conditions required for a community to gain enduring value from mining include: 'normalisation' rather than being a 'closed' town; existence of government support and funding; and realised economic diversification opportunities. It is imperative that these conditions are given due consideration: 1) in the initial stages of mine and town planning, and 2) throughout the life of the mine through ongoing monitoring and community engagement. However, we acknowledge the shortcomings in assuming planning is a panacea and suggest areas for further testing.
\end{abstract}

\section{Introduction}

Australia, and indeed the world, are replete with examples of unsuccessful mining towns which have collapsed or disappeared following the end of a boom period and the subsequent closure of an associated mine. Identifying why these towns have collapsed while others have succeeded has been uppermost in the minds of scholars ${ }^{1}$ for decades.

Recently, concepts such as Corporate Social Responsibility (CSR) and Social Licence to Operate (SLO) have become common language in mining companies. Indeed, since 2003, the peak mining bodies, such as the Minerals Council of Australia ${ }^{2}$ and the International Council for Mining and Metals, ${ }^{3}$ have established the need for their members to plan to help create enduring value for communities that have a stake in the success or otherwise of their mine. By providing enduring value, a community can continue to flourish long after the associated mine has closed. Planning not only during the life of the mine but also for the shutdown, start-up, or care and maintenance has, therefore, become centre-place for government, communities and mining sector decision makers. Planning provides the opportunity to transfer benefits not only to local workers in the mines but also more broadly to the community beyond the life of the mine. ${ }^{4}$

\footnotetext{
1 K Webb, 'Political Risk Insurance, CSR and the Mining Sector: An Illustration of the Regulatory Effects of Contracts' (2012) 54 International Journal of Law and Management 394, doi: 0.1108/17542431211264287; D Houghton, 'LongDistance Commuting: A New Approach to Mining in Australia' (1993) 159 The Geographical Journal 281; William R Freudenburg and Scott Frickel, 'Digging Deeper: Mining-Dependent Regions in Historical Perspective' (1994) 59 Rural Sociology 266; Keith Storey, 'Fly-in/Fly-out and Fly-Over: Mining and Regional Development in Western Australia' (2001) 32 Australian Geographer 133; Britt Dale, 'An Institutionalist Approach to Local Restructuring: The Case of Four Norwegian Mining Towns’ (2002) 9 European Urban and Regional Studies 5.

2 Minerals Council of Australia, Enduring Value: The Australian Minerals Industry Framework for Sustainable Development (Department of Industry, Tourism and Resources, 2005).

3 International Council for Mining and Metals, Ten Principles of Sustainable Development Performance (2003).

${ }^{4}$ Minerals Council Australia, Leading Practice Sustainable Development for the Mining Industry: Mine Closure and Completion (Department Industry Tourism and Resources, 2006).
} 
This line of research is markedly differentiated from others in this field of inquiry by considering the role that planning for mine lifecycles has on associated remote communities. ${ }^{5}$ Indeed, a key characteristic of remote communities is that they are highly vulnerable to the closure of any business and even more so to the closure of a relatively large local mining operation. ${ }^{6}$ Mining brings much needed opportunities for employment, raised income, increased property demand, taxes, rates, royalties, infrastructure and services. Moreover, many remote locations in Australia are over represented by Aboriginal people, ${ }^{7}$ a societal group of chronic disadvantage. ${ }^{8}$ For these reasons, planning becomes even more of an imperative for sustaining remote communities. Using a thematic review of the literature, this paper attempts to answer the research question: What is it that characterises mine lifecycle planning and what are the key factors which prevent or ensure enduring community value for mine-associated, remote communities?

The remainder of the paper is set out in the following manner. The second section defines and reviews the concept of mine lifecycle planning. The third section reviews the concept of enduring community value from mining. The fourth and fifth sections examine the concept of CSR and SLO. The sixth and tenth sections examine the social and economic impacts of mining and the concept of developing a sustainable economic base for communities through diversification and normalisation of company towns respectively. Policy concerns, limitations of our analysis, and areas for future research are elucidated in the final section of the paper.

\section{Mine lifecycle planning}

We defined mine lifecycle planning as the planning process involved in the development of a potential mineral extraction operation, where its lifecycle is planned from at least commencement of mining and ideally from the exploration stage.

Mine lifecycle planning has four stages: exploration, project development, operations, and mine closure. ${ }^{9}$ If the exploration stage confirms there is a mineral deposit that can be mined economically, the project development stage begins. The exploration and project development stages often overlap. ${ }^{10}$

The project development stage comprise numerous components, including: environmental and social impact assessments; development of sustainability and community programmes; and regulatory and government approvals. ${ }^{11}$ It is at the project development stage that the concept of generating enduring value from mining for an affected community should be considered. For example, Franks suggests that a mine plan should aim for outcomes that enhance the post-resource futures of the region surrounding the mine project. $^{12}$

Figure 1 shows an expanded form of the four stages of the mine lifecycle (exploration, project development and closure stages expanded) and how any expansions or material changes in the operations trigger additional environmental impact assessments. Figure 1 also highlights that stakeholder engagement occurs throughout the life of a mine, providing a critical link later to community approval.

Figure 2 shows the changes in the mine lifecycle that are likely to occur over time and the typical duration of each stage. Only recently have the impacts of post-closure been considered as part of the mine lifecycle. ${ }^{13}$ The temporary closure, as shown in Figure 2, or the placement of a mining operation into a care and maintenance mode can occur as a result of changes in commodity prices, which makes the operation une-

\footnotetext{
${ }^{5}$ This research was supported by the CRC for Remote Economic Participation (CRC REP) and the University of New England; the views expressed herein do not necessarily represent the views of the CRC REP, its participants or the University of New England. The authors are grateful to Profs Fiona Haslam-McKenzie and Neil Argent for their helpful comments on earlier drafts of this paper.

${ }^{6}$ B D Blackwell and B Dollery, 'Income Factor Shares from Mining in Remote Australia: An Analysis of the Ranger Uranium Mine and the Tanami Gold Mine in the Northern Territory' (2013) 19 Australasian Journal of Regional Studies 369.

Australian Bureau of Statistics, Cat No 4102.0 - Australian Social Trends (Australian Bureau of Statistics, 2008).

8 Australian Government, Closing the Gap: Prime Minister's Report 2014 (Australian Government, 2014).

9 D Meehan, 'Lifecycle of a mine' (2012) <http://www.sundanceresources.com.au/IRM/Company/

ShowPage.aspx/PDFs/2414-18580153/PresentationattheCameroonMiningForum> accessed 14 Dec 2012

${ }^{10}$ Ibid.

${ }^{11}$ Ibid.

${ }^{12}$ D Franks, Social Impact Assessment of Resource Projects (Mining for Development: Guide to Australian Practice (IM4DC, 2012).

${ }^{13}$ M Veiga, M Scoble and M McAllister, 'Mining with Communities' (2001) 25 Natural Resources Forum 191, doi:10.1111/j.1477-8947.2001.tb00761.x.
} 
conomical, or as a result of geotechnical conditions, including flooding or mechanical failure. ${ }^{14}$ The placement of the mine into care and maintenance mode can have significant effects on surrounding communities due to the reduction in the required workforce and the often sudden and unplanned nature of the change in operations. ${ }^{15}$

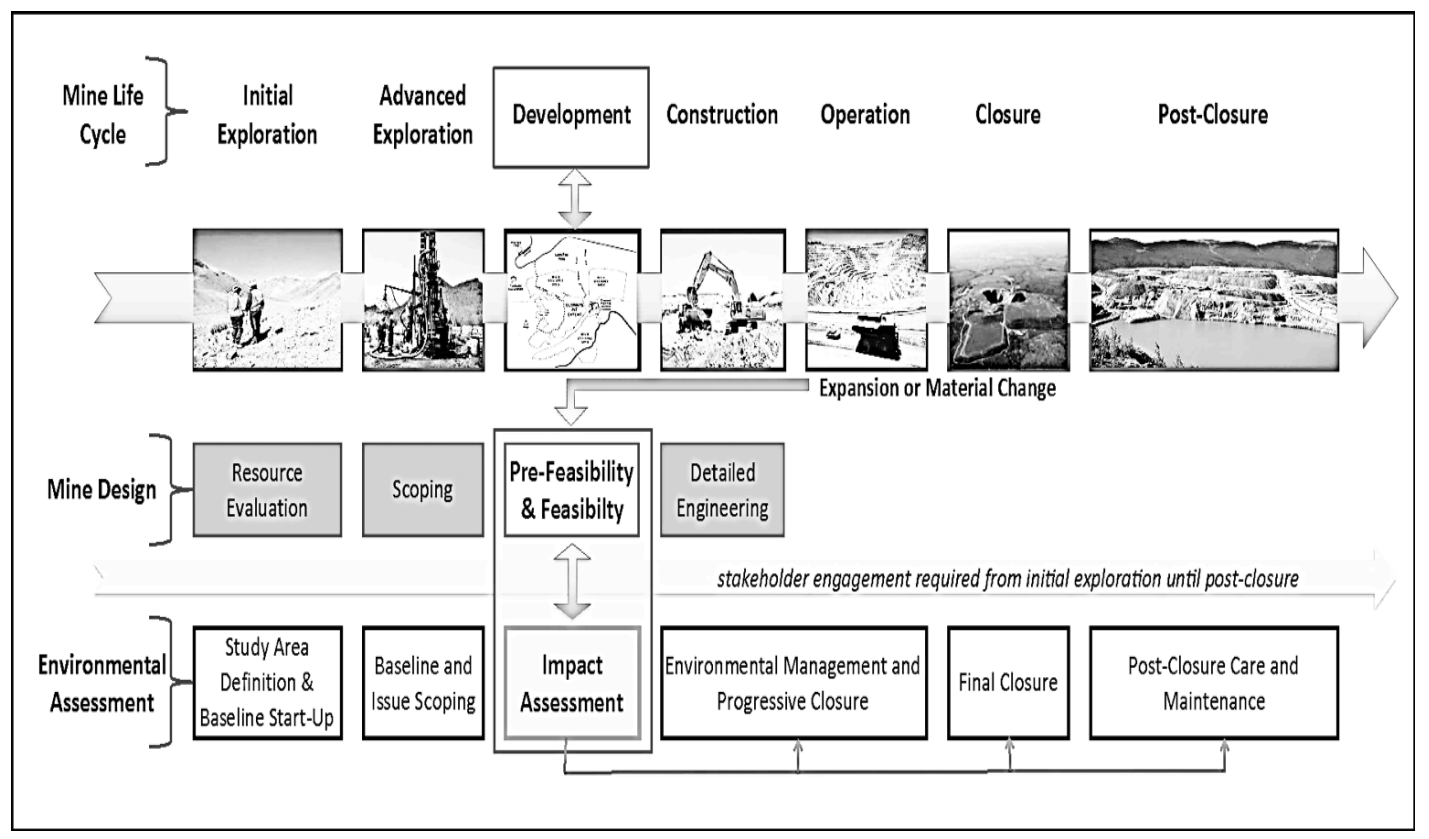

Figure 1: Four stages of the mine lifecycle (Source: Paredes) ${ }^{16}$

Planning for the closure of a mine is now recommended as part of the pre-feasibility studies for a mine. ${ }^{17}$ At the pre-feasibility stage, consideration should be given to whether it is possible to have a sustainable community built around the mine or if there is a need for a Fly-In-Fly-Out (FIFO) workforce. ${ }^{18}$ The pre-feasibility stage is also where the economic viability of the mine is assessed, based on the estimated operational costs, establishment costs and the market price of the resource being mined. This planning process also establishes baseline figures to assess the continuing viability of the mine. ${ }^{19}$ There is limited literature on mine lifecycle planning, with the main body of literature focusing on planning for the closure of the mine and the impacts of mine closure on the local communities. ${ }^{20}$ However, as can be seen from Figures 1 and 2 , mine closure is only part of the overall mine lifecycle and impacts from the mine occur throughout its life, even

${ }^{14}$ Minerals Council Australia, 'Leading Practice Sustainable Development for the Mining Industry: Mine Closure and Completion' (Department Industry Tourism and Resources, Canberra, 2006).

${ }^{15}$ see A Browne, D Stehlik and A Buckley, 'Social Licences to Operate: For Better not for Worse; for Richer not for Poorer? The Impacts of Unplanned Mining Closure for "Fence Line" Residential Communities' (2011) 16(7) Local Environment 707; see also B Pini, R Mayes and P McDonald, 'The Emotional Geography of a Mine Closure: A Study of the Ravensthorpe Nickel mine in Western Australia' (2010) 11(6) Social and Cultural Geography 559, doi: $10.1080 / 14649365.2010 .497850$.

${ }^{16}$ A Paredes, 'Mine Design and Environmental Assessment' (Impact Assessment and Responsible Development for Infrastructure, Business and Industry, Puebla, Mexico, 2011).

${ }^{17}$ Australian and New Zealand Minerals and Energy Council and Minerals Council of Australia, 'Strategic Framework for Mine Closure' (2000) <http: / /www.sernageomin.cl/pdf/material/StrategicFrameworkMineClosure.pdf>; J Stacey et al, 'The Socio-Economic Aspects of Mine Closure and Sustainable Development-Guideline for the Socio-Economic Aspects of Closure: Report 2' (2010) 110 The Journal of The Southern African Institute of Minng and Metalurgy 395.

${ }^{18}$ D Van Zyl at al, 'Mining for the Future Main Report' (International Institute for Environment and Development, 2002) <http://pubs.iied.org/pdfs/G00560.pdf>.

19 J Bhattacharya, Principles of Mine Planning (Allied Publishers, 2007).

${ }^{20}$ Centre for Sustainabilty in Mining and Industry, 'The Socio Economic Aspects of Mine Closure and Sustainable Development: Literature Overview and Lessons for the Socio-Economic Aspect of Closure Report 1 of 2' (Coaltech, project 7.8.5, 2010) <http://www.coaltech.co.za/chamber\%20databases/coaltech/Com_DocMan.nsf/0/ 13C0E50053B60B8788257AF4003392EC/SFile/Coaltech\%20Mine\%20Closure\%20Report\%201\%202010.pdf >; M Haney and M Shkaratan, 'Mine Closure and its Impact on the Community: Five Years after Mine Closure in Romania, Russia and Ukraine' (World Bank, 2003) <http://papers.ssrn.com/sol3/papers.cfm?abstract_id=636445>; D Hegadoren and J Day, 'Socioeconomic Mine Termination Policies: A Case Study of Mine Closure in Ontario' (1981) 7(4) Resources Policy 265; A James, S van Niekerk and B Stobart, 'Mine Closure Planning - Time for a Holistic Approach' (2005) 13(8) Civil Engineering: Magazine of the South African Institution of Civil Engineering 20; M Johnston, B Lorch and D Challen, 'Views of Community Sustainability After a Mine Closure: A Case Study of Manitouwadge, Ontario' (2004) 32(1) Environments 15; Stacey at al., above 17. 
well before and after closure of the mine. Therefore, mine lifecycle planning differs materially from mine closure planning because the planning horizon covers the entire life of the mine. Furthermore, we argue that planning for closure should occur over the life of the mine.

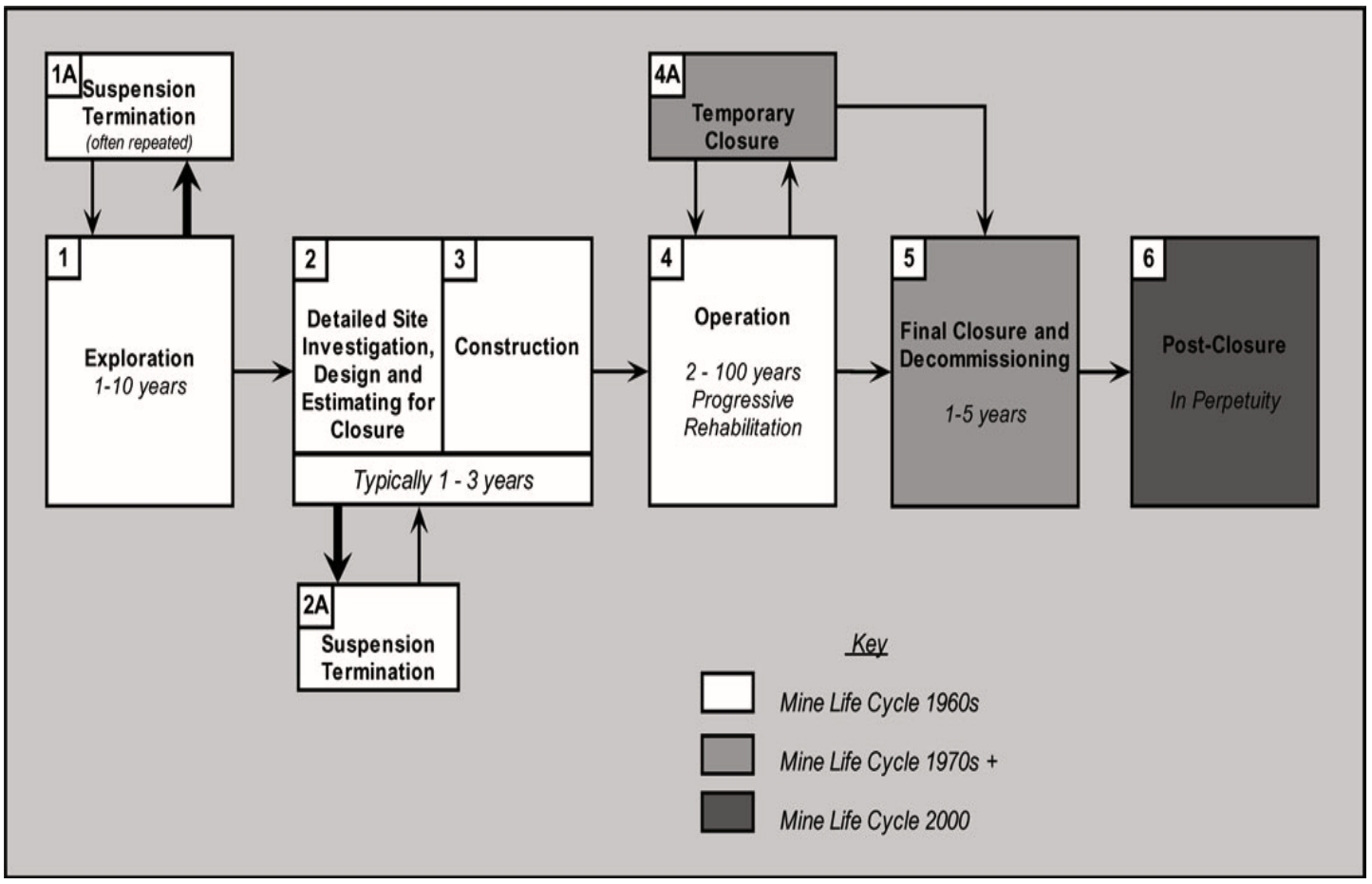

Figure 2: Temporal nature of the mine lifecycle (Source: Hodge) ${ }^{21}$

\section{Enduring community value from mining}

Enduring community value from mining entails providing a 'lasting or persistent benefit to groups of people and entities who have a stake in this economic activity'. ${ }^{22}$ The concept of enduring community value from mining is built upon the concept of sustainable development; the literature more commonly refers to sustainable development of communities rather than the concept of enduring community value from mining. ${ }^{23}$ Hodge considered that the success of a mining activity should be judged on its contribution to the wellbeing of the associated communities and the environment. ${ }^{24}$ Thus, by the end of the mine lifecycle, the affected communities should be more viable, durable and equitable than they were before mining commenced. ${ }^{25}$ Veiga et al defined a sustainable mining community as being 'one that could realize a net benefit from the introduction of mining that lasts through the closure of the mine and beyond' ${ }^{26}$

As noted by Veiga et al, three pillars for a sustainable community from the literature on sustainable development include: 1) ecological sustainability; 2) economic vitality; and 3) social equity. The challenge for mining companies in planning for a development is to ensure that these pillars are achieved by ensuring that environmental impacts pose no unacceptable risks, communications between the company and communities are transparent and effective, and the community perceives that they will gain a net benefit from the development. ${ }^{27}$

The Minerals Council of Australia (MCA) in association with the Department of Industry Tourism and Resources has developed guidelines entitled 'Enduring Value - The Australian Minerals Industry Framework for

\footnotetext{
${ }^{21}$ R Hodge, 'Mining's Seven Questions to Sustainability: From Mittigating Impacts to Encouraging Contribution' (2004) 27(3) Episodes 177.

22 J Davies, Y Maru and T May, 'Enduring Community Value from Mining: Conceptual Framework' (Working Paper cw007, Ninti One Limited, 2012) <http://www.crc-rep.com.au/resource/CW007_EnduringCommunityValueFromMining ConceptFwork.pdf>.

23 Ibid.

${ }^{24}$ Hodge, above n 21.

${ }^{25}$ Davies, Maru and May, above n 22.

${ }^{26}$ Veiga, Scoble and McAllister, above n 13.

27 Ibid.
} 
Sustainable Development'. ${ }^{28}$ The framework was developed from the International Council on Mining and Metals 'Sustainable Development' principles. ${ }^{29}$

Members of the Minerals Council of Australia are required to follow this framework despite no legal imperative to do so. The framework is more about stating aims than providing guidance to what will generate enduring value to a mining community. The concept of enduring value or sustainable development contrasts with the mitigation of the adverse effects of mining. Enduring value encompasses achieving a positive contribution to the community from mining and not just the mitigation of adverse effects. ${ }^{30}$

There has been an increasing recognition from mining companies that they have to be aware and plan for enduring value for mining-affected communities post closure as part of their SLO. Indeed, the concepts of SLO, CSR and sustainable development overlap. ${ }^{31}$

\section{Corporate social responsibility}

Though there was literature from the 1930s and 1940s on CSR, it was not until the 1950's that literature into CSR expanded. Social responsibility refers to business' obligations to pursue policies, make decisions, or follow actions which are desirable given society's objectives and values. ${ }^{32}$ Hamann proposed four necessary conditions to achieving CSR, it must: 1 ) go beyond philanthropic community investment and environmental impact mitigation; 2) embrace economic, social and environmental aspects of sustainability in a holistic manner; 3 ) be integrated into core activities and decision making of a company to provide maximum benefit; and 4) a mind-shift away from confrontation towards constructive engagement. ${ }^{33}$

Friedman eloquently covered the concept of social responsibility in 1962: 'few trends could so thoroughly undermine the very foundations of our free society as the acceptance by corporate officials of a social responsibility other than to make as much money for their stockholders as possible'. ${ }^{34}$ While Friedman's view is encountered amongst mining company managers who are concerned, this may 'lead to the company becoming enmeshed in local political struggles or community conflict', such a view is not expressed in public corporate communications. ${ }^{35}$ Hamann argues that globalisation and company power, the sustainability challenge, ethics in business and the business case for CSR mean that corporate greed is balanced by CSR. $^{36}$

Through the launch of the Global Mining Initiative (GMI) in 1998, CSR was promoted within the mining sector. ${ }^{37}$ The GMI was developed by leading mining and metals companies to chart a path for their industry's role in the transition to sustainable development and to ensure the industry contributed to long-term sustainable development. The GMI resulted in sustainable development analysis of the industry, a global conference, and a global leadership body for the industry - the International Council on Metals and Mining (ICCM). The establishment of GMI and the resurfacing of the concept of CSR were in response to campaigning by transnational Non-Government Organisations (NGOs) over social and environmental concerns. ${ }^{38}$

\footnotetext{
${ }^{28}$ Minerals Council Australia, 'Enduring Value the Australian Minerals Industry Framework for Sustainable Development' (Department of Industry, Tourism and Resources, Canberra, 2005).

29 International Council for Mining and Metals, '10 Princples of Sustainable Development Performance' (Intenational Council for Mining and Metals, 2003) <http://www.icmm.com/library>.

${ }^{30}$ Hodge, above $\mathrm{n} 21$.

31 J Lacey, R Parsons and K Moffat, 'Exploring the Concept of a Social Licence to Operate in the Australian Minerals Industry: Results from Interviews with Industry Representatives' (EP125553, CSIRO, October 2012).

${ }^{32}$ A Carroll, 'Corporate Social Responsibility: Evolution of a Definitional Construct' (1999) 38(3) Business and Society 268.

${ }^{33}$ R Hamann, 'Mining Companies' Role in Sustainable Development: The 'Why' and 'How' of Corporate Social Responsibility from a Business Perspective' (2003) 20(2) (2003/06/01) Development Southern Africa 237.

34 Ibid; quoted in Carroll, above n 32.

${ }^{35}$ Hamann, above n 33.

36 Ibid.

${ }^{37} \mathrm{H}$ Dashwood, 'Canadian Mining Companies and the Shaping of Global Norms of Corporate Social Responsibility' (2005) 60(4) International Journal 977, doi:10.2307/40204094.

38 Ibid; Hevina S Dashwood, 'CSR norms and Organizational Learning in the Mining Sector' (2012) 12(1) Corporate Governance 118.
} 


\section{Social licence to operate}

SLO represents having at least the acceptance and approval, and at most, the support and consent of local communities to operate. ${ }^{39}$ Mining company and mining peak body executives view SLO as going beyond compliance and important as a prerequisite for gaining a formal operational licence. ${ }^{40}$ In this context, mining companies need to consider the development and maintenance of a SLO as part of the mine lifecycle process.

SLO is a critical component of the concept of $\mathrm{CSR}^{41}$ because it is a 'community's perceptions of the acceptability of a company and its local operations'. ${ }^{42}$ SLO was 'developed as a response to a United Nations initiative that requires industries that operate in the territories of indigenous people to secure free, prior and informed consent from those indigenous people'. ${ }^{43}$

SLO is not just an abstract concept but also one that can be measured through four elements: 1) economic legitimacy; 2) socio-political legitimacy; 3) international trust; and 4) institutionalised trust. ${ }^{44}$ The measurement and monitoring SLO would form part a lifecycle planning process. As an example of SLO measurement, Boutilier and Thomson found a positive relationship between the stringency of SLO granted, and the socio-political risk faced by the company ${ }^{45}$ and associated costs of the mining operation. ${ }^{46}$ The higher the socio-political risk, the higher the costs of negotiation, mitigation of impacts and broader management of social, environmental and economic issues associated with the mine, and therefore the more stringent would be the requirements for an SLO.

Owen and Kemp are critical of the SLO concept because they believe it emerged as a response to opposition to the mining industry. ${ }^{47}$ They "argue that rather than open up critical enquiry "social license" serves to limit discussion and debate' about the industry's role in poverty alleviation and sustainable development. ${ }^{48}$ In contrast, Lacey et al considered that, over time, the importance of SLO would increase as communities would become more empowered through increased availability of information through the media. ${ }^{49}$

Interestingly, companies can operate within a CSR framework but may not necessarily gain a SLO to operate at the local level. ${ }^{50}$ On the other hand, operating in a sustainable development or CSR framework is a necessary condition to gaining and maintaining a SLO at the community level.

\section{Mine lifecycle planning: Economic and social impacts}

Although there is a paucity of research on the impacts of mine lifecycle planning and the creation of enduring value from mining for regions, there has been a great deal of research into the impacts of mining on communities upon the closure of a mine. ${ }^{51}$ Closure impacts can cause significant economic dislocation to mine-dependent communities, particularly those in remote Australia. In contrast, planning for the social and economic impacts in the development and construction phase of a major resource project can also pose considerable effects, including welcome local employment, though it means a construction workforce that brings a different social culture to town, and increased housing and property costs and general price rises. The early research into the impact of mining upon communities was conducted in Canada and the United States from the early 1970s. The majority of this research highlighted the negative effects of the boom and bust cycle of mining.

\footnotetext{
${ }^{39}$ Lacey, Parsons and Moffat, above $\mathrm{n} 31$.

${ }^{40}$ Ibid.

${ }^{41}$ Dashwood, above n 37; J Nelsen, 'Social License to Operate' (2006) 20(3) International Journal of Mining, Reclamation and Environment 161, doi:10.1080/17480930600804182; K Wilburn and R Wilburn, 'Achieving Social License to Operate Using Stakeholder Theory' (2011) 4(2) Journal of International Business Ethics 3.

42 R Boutilier and I Thomson, 'Modelling and Measuring the Social License to Operate: Fruits of a Dialogue Between Theory and Practice' (2011) 10 <http://socialicense.com/publications/Modelling\%20and\%20Measuring\%20the\%20SLO.pdf>

${ }^{43}$ Wilburn and Wilburn, above $\mathrm{n} 41$.

${ }^{44}$ Boutilier and Thomson, above $\mathrm{n} 42$.

${ }^{45}$ As cited in ibid.

${ }^{46}$ Webb, above $\mathrm{n} 1$.

${ }^{47}$ J Owen and D Kemp, 'Social Licence and Mining: A Critical Perspective' (2013) 38(1) Resources Policy 29.

${ }^{48} \mathrm{lbid}$

${ }^{49}$ Lacey, Parsons and Moffat, above n 31.

${ }^{50}$ Ibid.

51 see Browne, Stehlik and Buckley, above n 15 ; Centre for Sustainabilty in Mining and Industry, above n 20; Haney and Shkaratan, above n 20 ; Hegadoren and Day, above n 20 ; Johnston, Lorch and Challen, above n 20 ; Pini, Mayes and McDonald, above $\mathrm{n} 15$.
} 
The early research undertaken during the boom cycles of the 1970s and 1980s generated a hypothesis of social disruption on communities affected by mining. ${ }^{52}$ Moreover, later studies undertaken in North American communities during the bust cycle following the resources boom showed that mine-dependent communities did not achieve sustainable development. ${ }^{53}$ This finding has implications for planning and Veiga at a. remarked that planning for a sustainable mining community requires diversification of the economy through contributions from mining to the integrity or viability of the community and local environment. ${ }^{54}$

\section{Mine closure, care and maintenance operations}

Planning for mine closure can benefit the local community or region as well as the mining company, through developing viable economic alternatives, transforming mined land for the use of cash crops, and timing new mining projects to follow consecutively. ${ }^{55}$ The benefits to mining companies include: reducing the extent and cost of final remediation, lowering the risk of future strict regulation, reducing tension and conflict with local communities and improving the reputation of the company. ${ }^{56}$ Unplanned mine closures, or sudden placement of a mine operation into a care and maintenance mode, can have negative effects on communities surrounding the mine, especially those towns that have mine dependent economies. ${ }^{57}$

There are three general policy options for governments when a remote mine, upon which a community is dependent, faces closure: ${ }^{58}$ 1) refrain from any direct involvement; 2 ) assist the community to broaden its economic base via diversification; or 3 ) subsidise the mining operation to prevent its closure. The following factors should be considered in choosing a preferred option: 1) the degree to which a mine is integrated into regional and national economies; 2) the mining project's long-term financial viability; 3 ) prospects for successful diversification; 4) the nature of a mining community's population, particularly its age structure and the degree to which it is transient or settled; 5) the extent and ownership of community infrastructure; 6) the extent of the community's regional service role; 7) the existence of other producers of the mineral commodity concerned within the same political jurisdiction; and 8) the mining company's plans regarding allocation of capital and other resources withdrawn from a closed project. ${ }^{59}$

The total risk of mine closure $\left(R_{T}\right)$ can be assessed using a risk management matrix:

$$
R_{T}=\sum_{i=1,2, . . n}^{n} R_{i}
$$

where $R_{i}$ is an individual risk factor calculated as the product of the risk's probability and consequence. Total risk of a mine's closure is, therefore, the sum of all risk factor probabilities (eg 50\%) multiplied by their consequence (usually measured in dollar terms). Five risk factors to be considered are: 1 ) environmental; 2) safety and health; 3) community and social; 3) final land use; 4) legal and financial; and 5) technical. ${ }^{60}$ Such a model can be used for long-term planning and budgeting, and the risk assessment should be repeated by independent organisations at regular intervals to track changes in mine closure risk over time. ${ }^{61}$

\section{Diversification and building a sustainable economic base}

Diversification for the community must be part of the mine planning and operational process to achieve a net benefit to the community from the mine development. ${ }^{62}$ For example, Clemenson's study of single resource communities in Canada found communities that were able to diversify into other resources or

\footnotetext{
${ }^{52}$ M Smith, R Krannich and L Hunter, 'Growth, Decline, Stability, and Disruption: A Longitudinal Analysis of Social Wellbeing in Four Western Rural Communities’ (2001) 66 Rural Sociology 425, doi: 10.1111/j.1549-0831.2001.tb00075.x. 53 lbid.

${ }^{54}$ Veiga, Scoble and McAllister, above $\mathrm{n} 13$.

${ }^{55}$ A Warhurst and L Noronha, 'Corporate Strategy and Viable Future Land Use: Planning for Closure from the Outset of Mining' (2000) 24(2) Natural Resources Forum 153, doi:10.1111/j.1477-8947.2000.tb00939.x.

56 Ibid.

57 Ibid.

${ }^{58} \mathrm{C}$ O'Faircheallaigh, 'Mine Closures in Remote Regions: Policy Options and Implications' in C Neil, M Tykkyläinen and J Bradbury (eds), Coping with Closure: An International Comparison of Mine Town Experiences (Routledge, 1992).

${ }^{60}$ D Laurence, 'Optimisation of the Mine Closure Process' (2006) 14(3-4) Journal of Cleaner Production 285, doi:10.1016/j/jclepro.2004.04.011. 
industries had increased labour force participation in the period after the resource boom between 1981 and $1986 .{ }^{63}$

In another example, Tennant Creek in Northern Australia was originally gazetted in 1939 as a new town in response to a burgeoning mining boom population but now has diversified into a regional service, tourist destination and a meat-processing centre. Critically, Tennant Creek was never established as a company town and established a local council in 1978 with the Northern Territory Government actively supporting and funding the development of tourism, meat processing and regional service provision. ${ }^{64}$ Moreover, while anecdotal evidence suggests tactical planning for mining development helped with transition to other industries, eg placing miners in town as part of the development of a tourist caravan park rather than away from town, Tennant Creek's regional open plain pastures, and its strategic location to key highway cross-roads and for the laying of the transcontinental communication cable, resulted in employment diversification early in the town's development.

In a contrasting example, Marmoraton Mining Company in Marmora, Ontario, found that the local government committee appointed to attract new industry 'lacked the expertise and financial resources to adopt and coordinate senior government programmes for industrial expansion and diversification' ${ }^{65}$ Consideration of alternative uses of the site continues today and includes a failed landfill site for Toronto ${ }^{66}$ and a yet-tobe-approved water storage and hydroelectric facility. ${ }^{67}$

A range of options exist to revitalise ailing economies: ${ }^{68} 1$ ) encourage new exploration or re-mine tailings; 2) promote inexpensive housing options to retirees, younger families and artists; 3 ) develop tourism ventures; 4) diversification into other resource projects such as forestry, water, agriculture, aquaculture, ${ }^{69}$ bioreactor waste disposal, ${ }^{70}$ and geothermal energy for the local communities. ${ }^{71}$

There is also the potential for an existing community to become a hub for long distance commuting (LDC) workers to service new mines that may develop. Storey highlighted that the regional communities needed to be proactive in promoting their community as having the resources to support new mining developments either through services or as a workforce residence centre. ${ }^{72}$

\section{Normalisation of townships}

Normalisation of townships is 'the take-up of the operation and provision of services and facilities by local and other authorities, which have previously been provided and operated by companies'. ${ }^{73}$

To service and operate mines in remote areas, resource companies traditionally built townships surrounding the mine for the workers and their families. Once a stable population was established, the company was usually anxious to divest the responsibility of running a community to its members. ${ }^{74}$ Indeed, Lucas states that 'this inclination on the part of the company is supported by the provincial legislators who have made local self-government mandatory'. ${ }^{75}$

${ }^{63} \mathrm{H}$ Clemenson, 'Are Single Industry Towns Diversifying? A Look at Fishing, Mining and Wood-Based Communities' (1992) 4(1) Perspectives on Labour and Income 50.

${ }^{64}$ C O'Faircheallaigh, 'Economic Base and Employment Structure in Northern Territory Mining Towns' in T B Brealey, C C Neil and P W Newtown (eds), Resource Communities Settlement and Workforce Issues (CSIRO, 1988); see also O'Faircheallaigh, above $\mathrm{n} 58$.

${ }^{65}$ Hegadoren and Day, above $\mathrm{n} 20$.

${ }^{66}$ L Till, 'Old Mines Never Die...they Become Garbage Dumps' (1990) 76(34) The Northern Miner.

${ }^{67}$ Northland Power, Northland power <http://www.northlandpower.ca/WhatWeDo/Projects.aspx?projectID=349>

$68 \mathrm{~J}$ Kuyek and C Coumans, 'No Rock Unturned: Revitalizing the Economics of Mining Dependant Communities' (MiningWatch Canada, 2003).

${ }^{69}$ For an example of an aquaculture conversion, see J Mallo at al, 'Aquaculture: An Alternative Option for the Rehabilitation of Old Mine Pits in the Pampasian Region, Southeast of Buenos Aires, Argentina' (2010) 29(4) Mine Water and the Environment 285, doi:10.1007/s10230-010-0120-6.

${ }^{70}$ Veolia Environmental Services Australia, Bioreactor Landfill Technology, Resource Recovery and Sustainability <http://www.veoliaes.com.au/recycling-services/resource-recovery-facilities/bioreactor-landfills>.

${ }^{71}$ B Kynoch, 'Mining Heat' (2010) 51(3) Canadian Consulting Engineer 18.

${ }^{72}$ Storey, above $\mathrm{n} 1$.

${ }^{73}$ R Pilgram, 'Normalisation of the Pilbara Townships in Western Australia' in T B Brealey, C C Neil and P W Newtown (eds), Resource Communities: Settlement and Workforce Issues (CSIRO, 1988) 245.

${ }^{74}$ A Lucas, Life in Canadian Communities of Single Industry (Universtiy of Toronto Press, 1971). Ibid. 
An examination of remote resource communities of Australia and Canada highlights that the frontier culture of workers mean that frontier towns are destined to die based on the inherent boom-bust nature of the resource production systems. ${ }^{76}$ While frontier towns are a subset of remote towns, their lack of viability is particularly so where the towns were dependent on a single resource base. Bradbury suggests that the normalisation of mining communities into local government in both Australia and Canada may have been driven by the mining companies wishing to reduce their cost of providing housing and other necessary infrastructure for their workers. There has been encouragement from governments to normalise the structure of communities in British Columbia, Canada and the Pilbara region of Western Australia. For example, the Instant Towns Act 1965 in British Columbia enabled companies to pass control to local government and often involved the tearing down and rebuilding of a town's infrastructure. ${ }^{77}$

Contrastingly, in the Pilbara region, mines and towns were developed under specific agreements between mining companies and the Western Australian government. ${ }^{78}$ In 1977 the Western Australian government determined that new towns with a reasonable life expectancy be developed as open towns, that serviced land be developed by the state and be made available to mining companies and others, that changes be enabled to allow existing closed towns to achieve normal relationships and that the transfer of services to local government be negotiated to maintain service standards. ${ }^{79}$

Robinson and Newton further suggested that the sale of company homes to employees to start the 'normalisation' process in the township of Newman and Port Hedland in Western Australia was influenced by the fact that the homes were fully depreciated for tax purposes. ${ }^{80}$ In Canada, some provinces had buyback and compensation schemes in communities that had become normalised. ${ }^{81}$ In Australia, the push to normalise increased due to the introduction of the Fringe Benefit Tax (FBT) in $1985,{ }^{82}$ though Storey argues the contrary. ${ }^{83}$ Canada investigated the introduction of a similar tax regime but, due to protests, tax exemptions for housing and transport for employees in northern Canada were granted. ${ }^{84}$

Moving to a LDC workforce for mining companies reduces the need to build townships, further reducing infrastructure costs and liabilities upon closure of the mine. ${ }^{85}$ Some further factors encouraging the use of LDC are lower air travel costs and improvements in aircraft, improved communications, decreased staff turnover and absenteeism compared to resource town based staff, larger supply of qualified staff and a preference by workers and their families for metropolitan living. ${ }^{86} \mathrm{It}$ is interesting to note that the Standing Committee on Regional Australia Inquiry Into Fly-In-Fly-Out (FIFO) Work Practices made recommendations that Australian tax legislation be amended to encourage the development of remote townships as opposed to FIFO camps near mine sites.

\section{Socio economic impacts of mining}

Importantly mining can have negative as well as positive impacts on dependent communities, both of which need to be considered in planning processes. In Australia, negative effects include inflated housing costs, reduced staff retainment, increases in the population of single males, and real and perceived increases in criminal activity. ${ }^{87}$

\footnotetext{
${ }^{76} \mathrm{~J}$ Bradbury, 'Living with Boom and Bust cycles: New Towns on the Resource Frontier in Canada, 1945-1986' in T B Brealey, C C Neil and P W Newtown (eds), Resource Communities: Settlement and Workforce Issues (CSIRO Australia, 1988) 3.

${ }_{77}^{7 b i d .}$

78 Pilgram, above $\mathrm{n} 73$.

${ }^{79}$ Cited in ibid.

80 I Robinson and P Newton, 'Settlement Options for Non-Renewable Resource Development in Canada and Austrlalia: A Comparative Evaluation and Decision Framework' in T B Brealey, C C Neil and P W Newtown (eds), Resource Communities: Settlement and Workforce Issues (CSIRO, 1988).

${ }^{81}$ Bradbury, above $\mathrm{n} 76$.

${ }^{82}$ Robinson and Newton, above $\mathrm{n} 80$.

${ }^{83}$ Storey, above $\mathrm{n} 1$.

${ }^{84}$ P Parker, 'The Cost of Remote Locations: Queensland Coal Towns' in T B Brealey, C C Neil and P W Newtown (eds), Resource Communities: Settlement and Workforce Issues (CSIRO, 1988).

${ }^{85}$ Ibid; Bradbury, above $\mathrm{n} 76$.

${ }^{86}$ Ibid.

${ }^{87}$ See K Carrington and R Hogg, 'Benefits and Burdens of the Mining Boom for Rural Communities' (2011) Human Rights Defender; K Carrington and M Pereira, 'Assessing the Social Impacts of the Resources Boom on Rural Communities' (2011) 21(1) Rural Society 2, doi:10.5172/rsj.2011.21.1.2; F Haslam-McKenzie et al, 'Housing Market Dynamics in Resource Boom Towns' (No 135, AHURI, 2009); M Lawrie, M Tonts and P Plummer, 'Boomtowns, Resource Dependence and Socio-Economic Well-Being' (2011) 42(2) Australian Geographer 139, doi:10.1080/00049182.2011.569985; S Lockie
} 
Lawrie et al, in a cross sectional study on 33 resource communities in Western Australia, found that communities were characterised by their population size and stability, the mineral being extracted, remoteness, and the proportion of indigenous residents. ${ }^{88}$ Communities with a high level of remoteness also had a higher proportion of low-income households, though these proportions were lower than expected, possibly due to higher paid resource jobs. Lawrie et al further found that the proportion of indigenous population was positively associated with the level of low-income households. ${ }^{89}$

Langton and Mazel suggest that to minimise the socio-economic impact on Australian Aboriginal communities in remote mining areas, agreements between the Aboriginal title holders and mining companies should include strategies that build the capacity of the community. ${ }^{90}$ By doing so, during operation and postclosure of the mines, commercial enterprises can be developed that are not dependent on the mine for the long term. They further highlight that there would need to be increased investment in health, educational and other social infrastructure. ${ }^{91}$ Accordingly, many Indigenous organisations and communities may not have the capacity to take advantage of employment and commercial opportunities whilst also responding to the social impacts of mining. ${ }^{92}$

The use of the revenues in ways that are positive for development does assist communities to ensure they will have enduring value from the mining on their traditional lands. O'Faircheallaigh suggests that rent seeking behaviour by individual community members or by the company has the potential to negatively impact the development of enduring value from royalties. ${ }^{93}$ To avoid rent seeking behaviour, there need to be clear structures and policies on the use of the royalties as a part of the process of negotiating the agreements between the communities and mining companies. ${ }^{94}$ For example using royalties to educate children would not be rent seeking as it is adding to the human capital of the community.

However, agreements on employment quotas can also be used as a planning tool for creating enduring value but can have unintended consequences. In a report on the impact of northern Canadian Aboriginal communities, Gibson and Klinck found problems with employment quotas in communities, such as ${ }^{95}$ disruption of family life from a FIFO work structure, replacement of community languages with English, loss of traditional knowledge of the land, increased drug and alcohol use and domestic violence, and increased income disparity. Benefits included raised self-esteem of the community with the sense of independence and pride from working to overcome the legacy of dependence and poverty.

Richardson, in his study of the mining boom between 2004 and 2008, concluded that, overall, there was little positive impact to the majority of Australians. ${ }^{96}$ The positive impacts were primarily felt within the mining sector. The benefits that would have been expected to multiply through the economy were reduced due to changes in the terms of trade, increases in the value of the Australian dollar and increased interest rates. Richardson also found that real wages and government benefits indexed to wages 'increased at roughly the same rate after the onset of the mining boom as they did before'. ${ }^{97}$ Although there were exceptions in the case of Western Australia and Queensland, Altman highlights, in the Australian context, the reduction of public expenditure in regional and remote areas and the shifting of costs onto mining corpora-

at al, 'Coal Mining and the Resource Community Cycle: A Longitudinal Assessment of the Social Impacts of the Coppabella Coal Mine' (2009) 29 Envronmental Impact Assessent Review 330, doi:10.1016/j.eiar.2009.01.008; J Rolfe at al, 'Lessons from the Social and Economic Impacts of the Mining Boom in the Bowen Basin 2004-2006' (2007) 13(2) Australasian Journal of Regional Studies 134.

${ }^{88}$ Lawrie, Tonts and Plummer, above $\mathrm{n} 87$.

${ }^{89}$ Ibid.

${ }^{90}$ M Langton and O Mazel, 'Poverty in the Midst of Plenty: Aboriginal People, the "Resource Curse" and Australia's Mining Boom ' (2008) 26(1) Journal of Energy and Natural Resources Law 31.

${ }^{91}$ M Langton and O Mazel, 'The Resource Curse Compared: Australian Aboriginal Participation in the Resource Extraction Industry and Distribution of Impacts' in M Langton and J Longbottom (eds), Community Futures, Legal Architecture: Foundations for Indigenous Peoples in the Global Mining Boom (Routledge, 2012) 23.

92 J Altman, 'Contestations over development' in J Altman and D Martin (eds), Power, Culture, Economy: Indigenous Australians and Mining (The Australian National University, 2009).

${ }^{93}$ C O'Faircheallaigh, 'Curse or Opportunity? Mineral Revenues, Rent Seeking and Development in Aboriginal Australia' in M Langton and J Longbottom (eds), Community Futures, Legal Architecture: Foundations for Indigenous Peoples in the Global Mining Boom (Routledge, 2012) 45.

94 Ibid; Langton and Mazel, above n 90.

${ }^{95}$ G Gibson and J Klinck, 'Canada's Resilient North: The Impact of Mining on Aborignal Communities' (2005) 3(1) Pimatisiwin: A Journal of Aboriginal and Indigenous Community Health 116.

${ }^{96}$ D Richardson, The Benefits of the Mining Boom: Where Did They Go? (Technical Brief No 3 edn, The Australian Institute, 2009).

Ibid. 
tions which, as part of being socially responsible organisations, are filling the service gap within communities in order to maintain an SLO. ${ }^{98}$

\section{Discussion}

To many observers, the viability of a community and the viability of the town are inextricably linked. There are a multitude of factors that can impact on a mine alone: highly variable commodity prices, exchange rate variability, ore quality, confounding environmental factors and approvals, and the list goes on. Amongst these, an SLO and gaining social approval for the project are also important. Are these sufficient to stop a mining project? Examples exist: Jabiru in West Arnhem Land in Northern Territory has halted operations in 2013 to meet community and environmental concerns. However, is social viability a key to the mine's existence? One could argue not, but still important in the range of issues of concern.

A similar analysis could be undertaken on the viability of a town given its linkages with a mine. In remote Australia, many towns are established because of mine operations: Jabiru in the Northern Territory, Roxby Downs and Leigh Creek in South Australia, Onslow in Western Australia. Would these towns exist without mining? In many of these cases, the existence of the town hinges on the mine's existence; without the mine the town would not have come to be and will not continue in the future. For these reasons, we argue that where the mine is the reason for the town's existence, no matter how much planning is undertaken, the town will not exist without the mine.

In other instances, the towns began for other reasons such as in the case of Aboriginal settlements or ration stations. In these cases, people's connection to the land goes beyond the desire to profit from mineral extraction, though mineral extraction is often important to their ongoing wellbeing and opportunities for economic development. Again, similar to mine viability, town viability hinges on a number of factors, some of which can be planned for (endogenous) and others which are beyond the control of the town (exogenous). For these reasons, our findings are limited by the exogenous nature of mine operations, which, in turn, can determine the fate of a dependent town. The key to dealing with exogenous factors is for a town's economy to be as diversified as possible to help it build resilience and withstand the shocks from global vibrations. Tennant Creek was an example of a town established for mining which had its own local government and has subsequently planned for and successfully achieved diversification.

A further limitation in our analysis is the inherent assumption that planning provides for better outcomes than otherwise. While there is a large body of theory showing that planning does provide positive effects, an equally large body of economic theory, that is, laissez faire economics, suggests otherwise. We are at least conscious of the potential limitations in the 'do-good' nature of planning, and command and control type approaches, and the perverse incentives and obscure outcomes such arrangements can create for the economy. ${ }^{99}$

In closing, a number of areas of research are worth pursuit. Firstly, research is needed into whether regular and independent assessment of closure risk throughout a mines lifecycle can help deliver enduring value for mine dependent communities. One would envisage that early warnings about mine viability would help communities plan for a future without mining.

Secondly, rigorous assessment of the socioeconomic impacts of mining on Aboriginal peoples is needed. ${ }^{100}$ Such assessments are necessary to help guide policy and plans around the complex nature of providing enduring value from mining for remote Aboriginal and Torres Strait Islander communities.

Lastly, empirical evidence on the effect that planning can have on remote, mine-dependent communities both closed and open, and Aboriginal or otherwise - is required. Such testing would elucidate those situations where planning can deliver enduring value at various stages of a mine's lifecycle, not just post-closure. Controlling for the wide range of factors that affect mine and community viability would be required in building such an evidence base.

\footnotetext{
${ }^{98}$ Altman, above n 92.

${ }^{99}$ M Friedman and R Friedman, Free to Choose: A Personal Statement (Harcourt 1990).

${ }^{100}$ Altman, above $\mathrm{n} 92$.
} 